\title{
Relationship Knowledge, Attitudes and Practices of Officers BPBD with Countermeasures Optimization Flood Disaster in Makassar City
}

\author{
Femi Marsya Andris*, Cahyono Kaelan, Armyn Nurdin \\ Faculty of Medicine, Hasanuddin University, Indonesia \\ *femimarsya8@gmail.com
}

\begin{abstract}
This study aims to assess the relationship the knowledge of Regional Disaster Management Agency officers to the optimization of flood disaster management in Makassar City; the attitude of Regional Disaster Management Agency officers towards optimizing flood disaster management in Makassar City; the practice of Regional Disaster Management Agency officers in optimizing flood disaster management in Makassar City.

The research was conducted at the Regional Disaster Management Agency in Makassar City. This type of research is quantitative with analytical survey research methods. The population in this study were all officers of the Regional Disaster Management Agency. The sample of this research is the officers of the Regional Disaster Management Agency in Makassar City, as many as 40 people consisting of 30 office staff and 10 field officers.

The results of the research by office staff and field officers showed that knowledge $(\mathrm{p}$ value $0.032<\alpha 0.05$ ), attitude ( $\mathrm{p}$ value $0.036<\alpha 0.05$ ), and practice ( $\mathrm{p}$ value $0.013<\alpha$ 0.05). This means that there is a significant relationship between the knowledge, attitudes and practices of Regional Disaster Management Agency officials on optimizing flood disaster management in Makassar City. Knowledge, attitudes, and good practices can make all Regional Disaster Management Agency officers more optimal in responding to emergencies in facing floods.
\end{abstract}

Keywords : Knowledge, Attitude, Practice, Optimization Of Disaster Management

Received August 2, 2020; Revised August 26, 2020; Accepted September 8, 2020

(7) (D) STRADA Jurnal Ilmiah Kesehatan, its website, and the articles published there in are licensed under a Creative Commons Attribution-ShareAlike 4.0 International License. 


\section{STRADA Jurnal Ilmiah Kesehatan}

DOI: $10.30994 /$ sjik.v9i2.365

ISSN: 2252-3847 (print); 2614-350X (online)

Vol.9 No.2 November 2020 Page.861-871

\section{BACKGROUND}

Indonesia is an archipelago located at the junction of four tectonic plates, namely the Asian Continent plate, the Australian Continent, the Indian Ocean plate and the Pacific Ocean plate. Indonesia is also located in a tropical climate with two seasons, namely hot and rainy, characterized by quite extreme changes in weather, temperature and wind direction. In the rainy season it usually floods Disturb channel distribution and because that Indonesia tend experienced inflationary pressure during January and February when the rainy season tends to peak. Wet conditions can be exacerbated by the La Nina weather phenomenon. La Nina (essentially El Nino's opposite), is a phenomenon that occurs on average once every five years, bringing cooler-than-average ocean temperatures in the tropical regions of the central and eastern Pacific Oceans. Therefore it causes wetter than usual weather in Southeast Asia, usually from November to February.

The United States is hit by floods due to heavy rainfall. The floods in Virginia, Maryland, New York and Pennsylvania were caused by continuous torrential rains as a result of tropical storm Lee's remnants, which hit the Gulf Coast, causing large amounts of snow and ice to melt resulting in flooding, splitting ice and discharge. rivers and creeks are increasing.

It was 1993 when there was a long storm, the Mississippi River overflowed its banks and flooded the 400,000 square miles that spanned nine states. The loss at that time was estimated at US $\$ 15$ billion. Every year at that time it rained almost every day in June and July (Evers 1993).

In January 2013, a very large area of Jakarta was hit by flooding. This affected more than 100,000 homes and resulted in the loss of the lives of more than 20 people. Also in February 2017 Jakarta was plagued by massive flooding which caused thousands of houses to be flooded with murky brown water, sometimes 1.5 meters deep. Data About Flood Incidents in Indonesia Around 1,554 Floods that occurred resulted in physical damage including 3,588 heavily damaged houses, 3,289 moderately damaged houses, 15,376 slightly damaged houses, 325 damaged education buildings, 235 damaged worship facilities and 78 damaged health facilities.

The National Disaster Management Agency (BNPB) stated that the incidence of this disaster in 2019 increased by 72 percent. Of the 1,586 incidents, hydrometeorological disasters were dominated because more than 98 percent or about 1,554 were due to floods and extreme waves. Two percent or about 32 events due to geological disasters. Physical damage includes 3,588 houses severely damaged, 3,289 houses moderately damaged, 15,376 houses were slightly damaged, 325 educational buildings were damaged, 235 worship facilities were damaged and 78 health facilities were damaged.

There were three disasters that claimed lives with the greatest losses, including floods and landslides in South Sulawesi on (1/22/2019) IDR 926 billion, Sentani, Papua (16/3) IDR 668 billion, and Bengkulu (27/3) temporary data of IDR 200 billion (BNPB, 2019).

\section{METHODS}

This research is a type of quantitative research using survey research design. This study aims to analyze the effect of knowledge, attitudes and practices on optimizing flood disaster management in Makassar City. This research was conducted in January - February 2020. The research location was at the Makassar City Regional Disaster Management Agency office. The main informants in this study were officers of the Regional Disaster Management Agency. This research has passed the ethical test with letter number: 11 / UN4.6.4.5.31 / PP36 / 2019. 


\section{STRADA Jurnal Ilmiah Kesehatan}

DOI: $10.30994 /$ sjik.v9i2.365

ISSN: 2252-3847 (print); 2614-350X (online)

Vol.9 No.2 November 2020 Page.861-871

\section{RESULTS}

1) The Relationship between Knowledge and Optimization of Flood Disaster Management in Makassar City

Table 1.1

Relationship between Knowledge and Optimization of Flood Disaster Management In

Makassar City

\begin{tabular}{cccccccc}
\hline \multirow{2}{*}{ Knowledge } & \multicolumn{6}{c}{ Optimization of flood disaster management } \\
\cline { 2 - 7 } & \multicolumn{2}{c}{ Optimal } & Not & Optimal & \multicolumn{2}{c}{ Total } & $p$ \\
& $\mathrm{n}$ & $\%$ & $\mathrm{n}$ & $\%$ & $\mathrm{n}$ & $\%$ & value \\
\cline { 2 - 7 } & 25 & 62.5 & 6 & 15.0 & 31 & 77.5 & \\
Enough & 4 & 10,0 & 5 & 12,5 & 9 & 22.5 & 0,032 \\
\hline Less & 29 & 72.5 & 11 & 27.5 & 40 & 100.0 &
\end{tabular}

Based on Table 1.1, it can be seen that from a total of 31 respondents (77.5\%), 25 respondents $(62.5 \%)$ obtained adequate knowledge $(62.5 \%)$, and 6 respondents $(15,0 \%)$. Meanwhile, from a total of 9 respondents $(22.5 \%), 4$ respondents $(10.0 \%)$ had less than optimal knowledge and 5 people (12.5\%) had less than optimal knowledge.

Then after that analysis was carried out Descriptive Statistics Crosstabs Using the Chi Square Test, based on the Pearson Chi Square correction, the $p$ value is 0.032 which means the $p$ value is $0.032<\alpha 0.05$. Thus, Ha in this study which states that there is a relationship between knowledge on optimization of flood disaster management is declared accepted and $\mathrm{HO}$ is rejected.

2) The Relationship between Attitudes and Optimization of Flood Disaster Management in Makassar City

Table 1.2

The Relationship between Attitudes and Optimization of Flood Disaster Management In Makassar City

\begin{tabular}{|c|c|c|c|c|c|c|c|}
\hline \multirow[t]{3}{*}{ Attitude } & \multicolumn{7}{|c|}{ Optimization of flood disaster management } \\
\hline & \multicolumn{2}{|c|}{ Optimal } & \multicolumn{2}{|c|}{ Tidak Optimal } & \multicolumn{2}{|c|}{ Total } & \multirow{2}{*}{$\begin{array}{c}p \\
\text { value }\end{array}$} \\
\hline & $\mathrm{N}$ & $\%$ & $\mathrm{n}$ & $\%$ & $\mathrm{~N}$ & $\%$ & \\
\hline Positive & 20 & 50,0 & 11 & 27,5 & 31 & 77,5 & \\
\hline negative & 9 & 22,5 & 0 & 0 & 9 & 22.5 & 0,036 \\
\hline Total & 29 & 72.5 & 11 & 27.5 & 40 & 100.0 & \\
\hline
\end{tabular}

Based on table 1.2, it can be seen that from a total of 31 respondents $(77.5 \%)$, there were 20 respondents $(50.0 \%)$ with an optimal positive category, and 11 respondents $(27.5 \%)$ who were not optimal (0\%). Meanwhile, from a total of 9 respondents $(22.5 \%)$ obtained attitudes with the optimal negative category as many as 9 respondents (22.5\%), and the attitude with the negative category that is not optimal does not exist.

Then after that analysis was carried out Descriptive Statistics Crosstabs Using the Chi Square Test, based on the Pearson Chi Square correction the $\mathrm{p}$ value is 0.036 which means the $\mathrm{p}$ value is $0.036<\alpha 0.05$. Thus, Ha in this study which states that there is a relationship between attitudes towards optimizing flood disaster management is declared accepted and $\mathrm{H} 0$ is rejected. 


\section{STRADA Jurnal Ilmiah Kesehatan}

DOI: $10.30994 /$ sjik.v9i2.365

ISSN: 2252-3847 (print); 2614-350X (online)

Vol.9 No.2 November 2020 Page.861-871

3) Relationship between Practices and Optimization of Flood Disaster Management in Makassar City

Table 1.3

Relationship between Practices and Optimization of Flood Disaster Management In Makassar City

\begin{tabular}{ccccccccc}
\hline Practice & \multicolumn{7}{l}{ Optimization of flood disaster management } \\
& \multicolumn{2}{c}{ Optimal } & \multicolumn{2}{c}{ No Optimal } & \multicolumn{2}{c}{ Total } & $p$ \\
& $\mathrm{~N}$ & $\%$ & $\mathrm{~N}$ & $\%$ & $\mathrm{n}$ & $\%$ & value \\
& 11 & 27,5 & 9 & 22.5 & 20 & 50,0 & \\
Yes & 18 & 45,0 & 2 & 5.0 & 20 & 50,0 & \multirow{2}{*}{0,013} \\
No & 29 & 72.5 & 11 & 27.5 & 40 & 100.0 & \\
\hline Total & 29 & &
\end{tabular}

Based on table 1.3, it can be seen that from a total of 20 respondents $(50.0 \%), 11$ respondents $(27.5 \%)$ found disaster management practices in the category of performing optimal practices $(27.5 \%)$, and 9 respondents in the non-optimal practice category. (22.5\%). Meanwhile, from a total of 20 respondents $(50.0 \%)$, it was found that 18 respondents did not practice optimal categories (45.0\%) and did not practice in the non-optimal category as many as 2 respondents $(5.0 \%)$.

Then after that analysis was carried out Descriptive Statistics Crosstabs using test Chi Square Test, then based on the Pearson chi square correction the $\mathrm{p}$ value is 0.013 , which means the $\mathrm{p}$ value is $0.013<\alpha 0.05$. Thus, Ha in this study which states that there is a relationship between the practice of optimizing flood disaster management is accepted and $\mathrm{H} 0$ is rejected

\section{DISCUSSION}

1. The Relationship between Knowledge and Optimization of Flood Disaster Management in Makassar City

Based on the results of the bivariate analysis, it can be seen that from a total of 31 respondents (77.5\%), 25 respondents $(62.5 \%)$ obtained adequate knowledge $(62.5 \%)$, and 6 respondents (15), 0\%). Meanwhile, from a total of 9 respondents $(22.5 \%), 4$ respondents $(10.0 \%)$ had less than optimal knowledge and 5 people $(12.5 \%)$ had less than optimal knowledge.

Based on the results of research with analysis Descriptive Statistics Crosstabs using test Chi Square Test, then based on Pearson Chi Square Correction Got the value $p$ value is 0.032 , which means $\mathrm{p}$ value $0.032<\alpha 0.05$. Thus, it can be concluded that there is a significant relationship between knowledge and optimization of flood disaster management in the city of Makassar.

According to Friedman (2007) that knowledge is the domain of behavior. The higher a person's knowledge level, the more lasting the behavior will be. In other words, officers who know and understand flood disasters will participate properly according to what they know. This can show that based on framework disaster preparedness made by LIPI and UNESCO, preparedness is grouped into four parameters, namely knowledge and attitude ( knowledge and attitude) emergency planning (emergency planning, warning system (warning system), and resource mobilization. The knowledge possessed affects disaster preparedness, especially for those who live in areas prone to natural disasters. Knowledge indicators are basic knowledge that should be possessed by individuals, including knowledge about disasters, causes and symptoms, as well as what to do in the event of a flood. Emergency planning is more concerned with knowing what actions will be prepared to deal with natural disasters. 


\section{STRADA Jurnal Ilmiah Kesehatan}

DOI: $10.30994 /$ sjik.v9i2.365

ISSN: 2252-3847 (print); 2614-350X (online)

Vol.9 No.2 November 2020 Page.861-871

Meanwhile, the warning system here is what the community will do to prevent disaster victims by means of existing warning signs. Meanwhile, the mobilization of resources in the community, such as through the skills that are followed and so on. (ISDR / UNESCO 2007).

This is in line with research conducted by Karmila (2017) on the preparedness of regional disaster management agencies for flood disaster management in Gowa Regency. In the results of his research, it was found that preparedness is disaster management carried out to increase public understanding of flood disasters that will soon occur or are unlikely to occur and be implemented every year and involve the government of Gowa Regency and the people of Gowa Regency who are often affected by flood disasters every year which have been compiled. structurally, namely: Contingency Socialization, Field Rehearsal.

Research conducted by Ibrahim (2014) showed that knowledge, practical attitudes and familiarity of emergency nurses in handling disaster preparedness in Saudi Arabia showed that knowledge has a significant relationship with disaster preparedness, so a program for preparedness education in disaster-prone schools is needed.

In a study conducted by Isti Khasanah (2016) with the title of study of the knowledge, attitudes and preparedness actions of junior high school students in the face of volcanic eruptions in Magelang Regency, the results showed that the level of preparedness knowledge of SMP IT Al-Umar students was in the fairly good category while students SMP Negeri 1 Muntilan has a good level of knowledge. This difference in knowledge is influenced by several factors including: disaster education, information, academic factors and experiences. The students' preparedness attitude of SMP IT Al-Umar and SMP Negeri 1 Muntilan was in the very good category. Experience is the basis for forming attitudes and caring students to be ready to anticipate disaster, especially for students of SMP IT AL-UMAR which are located in areas prone to natural disasters. Meanwhile, for SMP Negeri 1 Muntilan students, attitudes are formed from the knowledge that has been obtained about disasters. The preparedness action of SMP IT Al-Umar students is in good category. This can be seen from the student's ability to make participative maps. Students have also been able to identify the area around their residence based on the precarious conditions.

Research conducted by Nauli Efiarti Nasution (2012) on the influence of knowledge and attitudes of regional disaster management agency officers on flood disaster management in South Tapanuli district, the results showed that statistically there was an influence of knowledge and attitudes on flood disaster management with $\mathrm{t}$ count value. knowledge $=3.754>\mathrm{t}$ table $=2.042$ and attitude attitude $3.229<2.042$. It is recommended to the Head of the Regional Disaster Management Agency Office to propose various trainings, simulations, and to provide opportunities for further education and to recruit new officers with a disaster education background in order to better understand flood disaster management before, during and after a flood disaster.

Based on the results of this study, the researchers assume that the knowledge of Regional Disaster Management Agency officers is quite high, in this case the officers can take action of their knowledge, such as knowing the point / location of the flood area, and knowing where the gathering point for residents when hit by a flood disaster, as well as officers are always on standby in flood disaster management. 


\section{STRADA Jurnal Ilmiah Kesehatan}

DOI: $10.30994 /$ sjik.v9i2.365

ISSN: 2252-3847 (print); 2614-350X (online)

Vol.9 No.2 November 2020 Page.861-871

2. The Relationship of Attitudes Toward Optimization of Flood Disaster Management in Makassar City

Based on the results of the bivariate analysis shows that from the total it is known that out of a total of 31 respondents $(77.5 \%), 20$ respondents $(50.0 \%)$ obtained an attitude with an optimal positive category, and an attitude with a non-optimal positive category was 11 respondents. (27.5\%). Meanwhile, from a total of 9 respondents $(22.5 \%)$, there were 9 respondents $(22.5 \%)$ in the negative category, and there was no attitude with the negative category that was not optimal.

Based on the results of research with analysis Descriptive Statistics Crosstabs using test Chi Square Test, then based on Correction Pearson Chi Square got the value $p$ value is 0.036 , which means $p$ value $0.036<\alpha 0.05$. Thus it can be concluded that there is a significant relationship between attitudes towards optimizing flood disaster management in Makassar City.

Attitude is an opinion, a person's belief about an object or situation that is relatively accompanied by certain feelings and provides a basis for the person to make a response to behave in a certain way he chooses (Walgito, 2003).

Gibson's theory (2008) states that the attitude in this case, namely facing flood disasters, is one of the triggers for the indicator for assessing preparedness behavior. Attitude is one of the determinants of behavior because attitude is related to perception, personality and motivation. Attitude is defined as mental preparedness, which is learned and organized through experience, and has influence the way a person responds to other people, objects and situations around him. Attitude on phase preparedness, in the form of excessive behavior in the community due to the lack of information on how to prevent and modify hazards due to disasters if they occur. News that contains the magnitude of the consequences of a disaster without educational material often makes people nervous and raises unrealistic actions on an issue. Growing attitudes and knowledge in dealing with disasters is increasingly becoming an important part, especially in a country that is often hit by disasters such as Indonesia (Priyanto, 2006).

This research is in line with the research conducted by Dodon (2013), with the title of research on indicators of attitudes towards community preparedness in densely populated settlements, in his research it shows that positive attitudes of the community are $35(35.0 \%)$ and negative as much as $11(11.0 \%)$. obtained from this study $\mathrm{p}=$ 0.005 .

In line with research conducted by Rahmad Ridha (2017), with the title of the relationship between knowledge and attitudes of the community towards flood prevention measures in Lon Asan Village, Lembah Seulawah District, Aceh Besar District. So the results of the study showed that there were 39 people $(58.2 \%)$ of good category of flood prevention, 38 people $(56.7 \%)$ of good category knowledge of flood prevention, and 37 people $(55.2 \%)$ of flood prevention measures. \%) on good category, so the results showed that there was also a relationship between community attitudes with flood prevention measures ( $\mathrm{p}$-value $=0,000$ ) and a relationship between knowledge and flood prevention measures ( $\mathrm{p}$-value $=0.025)$.

The results of this study are in line with the research conducted by Saifuddin (2015), with the title of analysis of the level of community preparedness in facing flood disasters in Meurebo District, West Aceh Regency, in his research it shows that the level of public knowledge in dealing with flood disasters is insufficient (65.9\%), the majority of respondents' attitudes were negative (62.3\%), and lack of preparedness 


\section{STRADA Jurnal Ilmiah Kesehatan}

DOI: $10.30994 /$ sjik.v9i2.365

ISSN: 2252-3847 (print); 2614-350X (online)

Vol.9 No.2 November 2020 Page.861-871

(38.8\%). Statistical test results regression It was found that there was a significant influence between knowledge $(\mathrm{p}=0.001)$ and attitude $(\mathrm{p}=0.003)$ with the preparedness of the people of Meureubo District in facing flood disasters.

Based on the results of this study, the researchers assume that attitude is an indicator of preparedness as well as mitigation against flood disaster management. With a positive attitude from officers, it will affect the form of actions to be taken to the maximum flood disaster management.

3. Relationship between Practices and Optimization of Flood Disaster Management in Makassar City

Based on the results of the bivariate analysis, 11 respondents $(27.5 \%)$ found that out of a total of 20 respondents $(50.0 \%), 11$ respondents $(27.5 \%)$ found disaster management practices in the category of performing optimal practices, and 9 respondents (9 respondents). (22.5\%). Meanwhile, from a total of 20 respondents $(50.0 \%)$, it was found that they did not practice with optimal category was 18 respondents $(45.0 \%)$ and not doing practice with suboptimal category were 2 respondents $(5.0 \%)$.

Based on the results of the research by doing the analysis Descriptive Statistics Crosstabs using test Chi Square Test, then based on correction pearson chi square got the value $p$ value of 0.013 , which means the $p$ value is $0.013<\alpha 0.05$. Thus, Ha in this study which states that there is a relationship between the practice of optimizing flood disaster management is accepted and $\mathrm{H} 0$ is rejected.

This research is in line with research conducted by Dyah Rahmawati Hizbaron (2016), with the title Research Disaster Management Practices Towards Various Vulnerable Groups in Yogyakarta. The implementation of disaster management practices with Katana has made good progress in terms of community preparedness when floods occur. Basically, this change occurred due to the awareness arising from the location of private housing and community activities in direct contact with the Winongo river. The emergence of this awareness is supported by the formation of the Katana, which plays an important role in increasing community preparedness against disasters, especially floods, but coupled with knowledge of preparedness for natural disasters such as landslides, and social disasters such as crime in general.

In Aprilia Findayani's (2015) research with the title of research on community preparedness in flood prevention in the city of Semarang, it was found that the results of this study revealed that the community's practice of tackling flooding implemented by households was influenced by the economic level. The economic level affects the level of their readiness to face flooding. Focus shows that the communities in the study area apply a combination of economic, technological / structural and social related mechanisms in order to minimize the negative impact of flooding.

The results of this study are in line with Stuart N. Lane (2011) with the title of research on risk assessment and flood disaster management practices. Reliance on events is a challenge to predict, given the changing probability (eg climate change) and its consequences (eg floodplain development). Thus, risk management allows some elements of risk analysis to become unstable (particularly related to climate change) but forces others to remain stable (eg Implementing regulations to prevent improper development of floodplains). We conclude that the assumption of the separation of risk assessment and management is wrong because the calculation of risk must be 


\section{STRADA Jurnal Ilmiah Kesehatan}

DOI: $10.30994 /$ sjik.v9i2.365

ISSN: 2252-3847 (print); 2614-350X (online)

Vol.9 No.2 November 2020 Page.861-871

determined by management. Risk management should and continually define the set of practices that can be adopted, and should even be, scientifically analyzed.

According to Asmi who quoted the UNISDR statement ( United Nations International Strategy for Disaster Reduction) which states that disaster risk reduction aims to reduce the damage caused by natural disasters such as earthquakes, floods, tsunamis and hurricanes, through preventive ethics. Disaster risk reduction is a practical concept of reducing disaster risk through systematic efforts to analyze and reduce the factors that cause disasters. Reducing exposure to hazards, reducing human and property vulnerability, management proper management of land and environment and increasing preparedness for disaster impacts are examples of disaster risk reduction.

Disaster risk reduction includes disciplines such as disaster management, disaster mitigation and disaster preparedness, but DRR is also part of sustainable development. In order for development activities to be sustainable they must also reduce disaster risk.

Based on the results of this study, the researchers assume that the practice of the officers carried out is monitoring and providing reports on the conditions of areas affected by flooding during the rainy season, then the officers also have a personnel movement mechanism and have a contingency plan document when a flood occurs for flood disaster relief

\section{CONCLUSION}

1. There is a relationship between the knowledge of regional disaster management agency officers and the optimization of flood disaster management in the city of Makassar. With sufficient knowledge of the bpbd officer, in this case the officer can take the knowledge they have, such as knowing the point / location of the flood area, as well as knowing where the gathering point for residents when hit by a flood disaster, this can make officers always ready for flood disaster management. .

2. There is a relationship between the attitude of regional disaster management agency officers to the optimization of flood disaster management in the city of Makassar. Attitude is an indicator of preparedness and mitigation carried out by officers in this case to determine the effects of flood disasters. With a positive attitude from officers, it will affect what form of action will be taken towards maximum flood disaster management.

3. There is a relationship between the practice of regional disaster management agency officers and the optimization of flood disaster management in the city of Makassar. The practice of officers carried out is monitoring and providing reports on the condition of areas affected by flooding during the rainy season, then officers are ready to be on standby in the personnel movement mechanism and have a contingency plan document in the event of a flood for flood disaster prevention..

\section{REFERENCES}

Bakornas PB. 2007. Introduction to Disaster Characteristics and Mitigation Efforts at Indonesia.Jakarta: National Disaster Management Agency.

Bourque, LB, Shoaf, KI, and Nguyen, LH: Survey Journal International of Mass Emergencies and Disasters, 15,71-101, 1997.

Bwambale, B. Muhumuza, M. \& Nyeko, M., 2018, 'Traditional Ecological Knowledge And Flood Risk Management: A Preliminary Case Study Of The Rwenzori ', Jàmbá: Journal Internationals Of Disaster Risk Studies10(1), A536. 


\section{STRADA Jurnal Ilmiah Kesehatan}

DOI: $10.30994 /$ sjik.v9i2.365

ISSN: 2252-3847 (print); 2614-350X (online)

Vol.9 No.2 November 2020 Page.861-871

Https://Doi.Org/10.4102/ Jamba.V10i1.536.

Cardona, (2003), “The Need For Rethinking The Concept Of Vulnerability And Risk

AHolistic Perspective: ANecessary Review And CriticismForEffectiveRisk Management,"In

G. Bankoff, G. Frerks, And D. Hilhorst, Editor, Vulnerability Mapping: Disasters, Development and People, London, 2003.

Ri Social Department, Law of the Republic of Indonesia Number 24 of 2007 concerning Disaster

Management, ( Jakarta: Center for Social Counseling, 2007).

Dkkv (Deutsches Committee Fü R Katastrophenvorsorge). 2004. Flood Risk Reduction In

Germany: Lessons Learned From The 2002 Disaster In The Elbe Region. Dkkv Publication 29e. Bonn: German Committee For Disaster Reduction.

He Bs, Huang Xl, et al. Analysis Of Flash Flood Disaster Characteristics In China From2011 To 2015. Nat Hazards. 2018; 90 (1): 407-20.

Heidari, A., 2009, 'Structural Master Plan Of Flood Mitigation Measures', Natural Hazards And Earth System Sciences 9, 61-75. Https://Doi.Org/10.5194/Nhess- 9-61-2009.

Iloka, NG, 2016, 'Indigenous Knowledge For Disaster Risk Reduction: An African

Perspective ', Jàmbá: International Journal Of Disaster Risk Studies 8, A272. Https://Doi.Org/ 10.4102/ Jamba.V8i1.272.

Jha, V. \& Jha, A., 2011, 'Traditional knowledge on disaster management: A preliminary study of the Lepcha community of Sikkim, India ', Indian Journal of Traditional Knowledge 10,173-182.

Juergen Weichselgartner, Patrick Pigeon, 2015. The Role Of Knowledge In Disaster Risk Reduction Ministry of Social RI, Module for Disaster Management Social Assistance Officers, (Cet.I: Jakarta, 2011).

Ministry of Social RI, Association of Legislations for Disaster Management sosial.

Decree of the Minister of Home Affairs RI Number 46 of 2008 concerning Organizational Guidelines And Work Procedures for Regional Disaster Management Agencies.

Khaing Zaw Myo, Dkk, 2019. Flood Hazard Mapping And Assessment In Data-Scarce Nyaungdon Area, Myanmar.

Khaing Zm, Zhang K, Sawano H, Shrestha Bb, Sayama T, Nakamura K (2019) Flood Hazard Mapping And Assessment In Data-Scarce Nyaungdon Area, Myanmar. Plos One 14 (11): E0224558.

King, D., Goudie, D., and Dominey-Howes, D: Cyclone knowledge and house hold preparation -some insights from Cyclone Larry, The Australian Journal of Emergency Management, 21, $52-59,2006$.

Kodoatie, Robert J and Sugiyanto. 2002. Some of the Causes of Flood Control In an Environmental Perspective. Student Library, Yogyakarta.

Kolen, B., R. Slomp, W.Van Balen, T. Terpstra, M. Bottema, And S. Nieuwenhuis. 2010. Learning From French Experiences With Storm Xynthia: Damages After A Flood. AC Lelystad: Rijkswaterstaat Waterdienst.

Kreibich, H., Thieken, AH, Petrow, Th., Müller, M., and Merz, B .: Flood loss reduction of private households due to building precautionary measures - lessons learned from the Elbe flood in August 2002, Nat. Hazards Earth Syst. Sci., 5, 117-126, 2005. Lipi-Unesco / Isdr 2006. Study of Community Preparedness in Anticipating Disasters Earthquake And Tsunami. Unesco Office, Jakarta.

Mishra, S., Mazumdar, S. \& Suar, D., 2010, 'Place Attachment And Flood Preparedness', Journal International Pubmed Of Environmental Psychology 30, 187-197.

Https://Doi.Org/10.1016/J. Jenvp.2009.11.005. 


\section{STRADA Jurnal Ilmiah Kesehatan}

DOI: $10.30994 /$ sjik.v9i2.365

ISSN: 2252-3847 (print); 2614-350X (online)

Vol.9 No.2 November 2020 Page.861-871

Mcewen, L. \& Jones, O., 2012, 'Building Local/Lay Flood Knowledges Into Community Flood Resilience Planning After The July 2007 Floods, Gloucestershire, Uk', Hydrology Research 43, 675. Https://Doi.Org/10.2166/Nh.2012.022.

Negalign Berhanu Hailay Abrha Yohannes Ejigu Kifle Woldemichael, 2016. Knowledge, Experiences And Training Needs Of Health Professionals About Disaster Preparedness And Response In Southwest Ethiopia: A Cross Sectional Study.

Pahl-Wostl, C., G. Becker, C. Knieper, And J. Sendzimir. 2013. How Multilevel Societal Learning Processes Facilitate Transformative Change: A Comparative Case Study Analysis On Flood Management. Ecology And Society 18(4). Article No. 58. Pangesti, Asih Dwi Hayu. 2012. Gambaran Tingkat Pengetahuan dan Aplikasi Kesiapan Bencana pada Mahasiswa Fakultas IlmuKeperawatan Universitas Indonesia Tahun 2012. Tidak diterbitkan. Skripsi. Fakultas Ilmu Keperawatan Universitas Indonesia

Peraturan Menteri Dalam Negeri Ri Nomor 27 Tahun 2007 Tentang Pedoman Penyiapan SaranaPrasarana Dalam Penanggulangan Bencana.

Perdana, Nurdin. 2016. Menurunkan Resiko Bencana. Pertama.Ed. Andi M.Akhmar \& M. Nawir.Makassar: Masagena Press.

Pigeon, P. 2013. Flood Risk And Watershed Management Conflicts In France: Upper Catchment Management Of The River Rhone. In Making Space For The River: Governance Experiences With Multifunctional River Flood Management In The Us And In Europe, Ed. J.F. Warner, A. Van Buuren, And J. Edelenbos, 149-161. London: Iwa Publishing.

Ristika Pramadita Rosa Dkk, Peta Spasial Indeks Rawan Bencana Banjir Jawa Timur Menggunakan Sistem Informasi Geografis (SIG), Jurnal epidemiologi dan Biostatistika.

Roder, G.; Ruljigaljig, T.; Lin, C.-W.; Tarolli, P. Natural Hazards Knowledge And Risk Perception OfWujie Indigenous Community In Taiwan. Nat. Hazards 2016, 81, 641- 662.

Rosemary Mm. Knowledge, Attitudes And Practices Of Health Care Workers Regarding Disaster Preparedness At Johannesburg Hospital In Gauteng Province (Masters Thesis), South Africa, 2008.

Saulnier DD, Brolin Ribacke K, Von Schreeb J. No Calm After The Storm: A Systematic Review Of Human Health Following Flood And Storm Disasters. Prehosp Disaster Med. 2017;32(5):568-579. A Systematic Review Looking At All Health Effects Caused By Floods And Storms. It Shows An Increase In Wound And Lacerations After Storms, But None Of The Included Studies Looked At Injuries Caused By Floods.

Sinulingga, Sukaria. 2014. Metode Penelitian, Usu Press Universitas Sumatera Utara, Medan.

Sinha A, Pal D, Kasar P, Tiwari R, Sharma A. Knowledge, Attitude And Practice Of Disaster

Preparedness And Mitigation Among Medical Students. Disaster Prevention And Management: An International Journal. 2008;17(4):503-7.

Spiekermann, R., S. Kienberger, J. Norton, F. Briones, And J. Weichselgartner. 2015. The Disaster-Knowledge Matrix: Reframing And Evaluating The Knowledge Challenges In Disaster Risk Reduction. International Journal Of Disaster Risk Reduction 13: 96108.

Subandi, A., Alim, S., Haryanti, F. \& Prabandari, Y.S., 2019. 'Training On Modified Model Of Programme For Enhancement Of Emergency Response Flood Preparedness Based On The Local Wisdom Of Jambi Community', Jàmbá: Journal Internationals Of Disaster Risk Studies 11(1), A801. Https://Doi.Org/10.4102/Jamba.V11i1.801. Sugiyono, Metode Penelitian Kuantitatif Kualitatif, ( Bandung: Alpabeta, 2009) Sekertariat Badan Kordinasi 


\section{STRADA Jurnal Ilmiah Kesehatan}

DOI: $10.30994 /$ sjik.v9i2.365

ISSN: 2252-3847 (print); 2614-350X (online)

Vol.9 No.2 November 2020 Page.861-871

Nasional Penanggulangan Bencana Dan Penanggulangan Pengungsi, Panduan Pengenalan Karakteristik Bencana.

Tran, P., Shaw, R., Chantry, G. \& Norton, J., 2008, 'Gis And Local Knowledge In Disaster Management: A Case Study OfFlood Risk Mapping In Viet Nam', Disasters 33, 152-169.

Undang-Undang RI No.24 Tahun 2007. Tentang Penanggulangan Bencana. UNDP, 2013, Study of the flooding in Rwenzori Mountain for effective disaster risk management, UNDP Uganda, viewed 12 June 2017

UNISDR (United Nations International Strategy for Disaster Risk Reduction). 2014. Hfa Thematic Review: Research Area 2. Priority For Action 3-Core Indicator 1: Relevant Information On Disasters Is Available And Accessible At All Levels, To All Stakeholders (Through Networks, Development Of Information Sharing Systems Etc.). Background Paper Prepared For The 2015 Global Assessment Report On Disaster Risk Reduction. Geneva: Unisdr.

UNISDR (United Nations International Strategy For Disaster Risk Reduction). 2015a. Making Development Sustainable: The Future Of Disaster Risk Management. Geneva: Unisdr.

UNISDR (United Nations International Strategy For Disaster Reduction). 2015b. Sendai Framework For Disaster Risk Reduction 2015-2030.

Vladimir M. Cvetkovi'C Dkk 2018. The Role Of Gender In Preparedness And Response Behaviors Towards Flood Risk In Serbia.

Vojtek M, Vojtekova' J. Flood Hazard And Flood Risk Assessment At The Local Spatial Scale: A Case Study. Geomatics, Natural Hazards And Risk. 2016; 7(6):1973-92.

White, G.F., R.W. Kates, And I. Burton. 2001. Knowing Better And Losing Even More: The Use Of Knowledge In Hazard Management. Global Environmental Change Part B: Environmental Hazards 3(3-4): 81-92.

Yao C, Ye J, He Z, Bastola S, Zhang K, Li Z. Evaluation Of Flood Prediction Capability Of The Distributed Grid-Xinanjiang Model Driven By Wrf Precipitation. Journal Pubmed Of Flood Risk Management. 2019; 12(S1): E12544.

Yunus Jarmie Muhammad, Deli Anhar, 2017. Efektivitas Komunikasi Badan Penanggulangan Bencana Daerah (Bpbd) Kabupaten Banjar Dalam Mengurangi Resiko Bencana Banjir Di Kabupaten Banjar 